\title{
Wholegrain health claims in Europe
}

\author{
David P. Richardson \\ dprnutrition, 34 Grimwade Avenue, Croydon, Surrey CRO 5DG, UK
}

\begin{abstract}
Wholegrain foods are important sources of nutrients and phyto-protective components, which are in short supply in many member states of the EU, including the UK. Encouraging the public to increase consumption of wholegrain foods is a positive health message that has critical public health implications. In February 2002 the UK Joint Health Claims Initiative (JHCI) published its authoritative endorsement that wholegrain foods are associated with a healthy heart (Joint Health Claims Initiative, 2002). This new health claim reflects a similar one in the USA based on the accumulation of epidemiological evidence between 1996 and 2001 from several very large cohort studies in the USA, Finland and Norway, which show a consistent protective effect of whole grain and reduced risk of CHD. The JHCI code of practice on health claims requires that the claimed benefit must be scientifically valid, with evidence supporting efficacy of the food in human consumers, under typical conditions of use. The evidence-based approach consists of the identification of studies, an evaluation of individual references, a critical evaluation of the totality of the evidence and a statement that there is significant scientific agreement to establish the validity of the claim. The studies suggest that an intake of three servings per d may have an important cardio-protective effect. The development of a process for the substantiation of health claims in the UK and in the EU is important to underpin regulatory developments, which should protect the consumer, promote fair trade and encourage innovation in the food industry. The present paper sets out the format of the scientific dossier that was presented to the JHCI and includes a call to promote further research to identify the important protective components in the whole grain 'package' and the biological mechanisms behind the observed beneficial effects on health. The major sources of whole grain in the UK are bread and breakfast cereals, and $>90 \%$ of adults in the UK consume less than three servings per d. Increasing the variety and availability of acceptable wholegrain foods could lead to greater consumption levels, which has important public health implications and offers an attractive and food-based dietary strategy for targeting the whole population.
\end{abstract}

Whole grains: Health claims: Coronary heart disease

In the EU there is increasing interest in the subject of health claims and in the development of diets, foods and food components that provide physiological, cognitive and psychological benefits beyond their widely-accepted nutritional effects. The primary roles of diet are to provide sufficient nutrients to meet the metabolic requirements of an individual and to give the consumer a feeling of satisfaction and well-being through the pleasure of eating and drinking. In addition, many traditional foods including fruits and vegetables, wholegrain cereals and milk are being shown to contain physiologically-active components that may have health-promoting properties and that may help reduce the risk of certain chronic diseases.

As a result, in 1995 the EU set up a European Commission Concerted Action on Functional Foods in Europe under the
EU DGXII Fair Programme. The programme was coordinated by the International Life Sciences Institute Europe and the aim was to develop and establish a science-based approach to the evidence needed to support the development of food products that can have a beneficial effect on an identified physiological function in the body that can improve an individual's state of health and well-being and/or reduce the risk of disease (Bellisle et al. 1998). The European Commission Concerted Action on Functional Foods in Europe project supported the development of two types of health claims on foods that must always be valid in the context of the whole diet and must relate to the amounts of food or the food component that would normally be consumed. First, 'enhanced function' claims refer to specific physiological, psychological functions and biological activities beyond their 
established role in growth, development and other normal functions of the body; second, 'reduction of disease risk' claims relate to the consumption of a food (or foods) or food component(s) that might help reduce the risk of a specific disease or condition because of specific nutrients or nonnutrients contained within them (Diplock et al. 1999).

More recently, a new EU Commission Concerted Action programme, also coordinated by International Life Sciences Institute Europe, is aiming to resolve some of the ongoing issues of validation and scientific substantiation of claims (International Life Sciences Institute Europe, 2001). This project, Process for the Assessment of Scientific Support for Claims on Foods, is undertaking a critical evaluation of existing international schemes for the scientific substantiation of health claims, with a view to identifying best practice and a methodology to underpin current and future EU regulatory developments on health claims (Richardson et al. 2003).

\section{Regulatory issues}

Several European countries have already developed guidelines and codes of practice on what to do with health claims (Leatherhead Food Research Association, 2001). Many of these national codes evolved in the absence of an EU directive on health claims. However, in July 2002 the Commission of the European Communities published a draft proposal for regulation of nutrition, functional and health claims (Commission of the European Communities, 2002), which aims to harmonise the approach to health claims and to set out the scientific basis to substantiate claims for functional components or the foods containing them. There is broad consensus that any regulatory framework for the use of health claims should protect consumers from false and misleading claims, promote fair trade and encourage innovation in the food industry.

Although nutritional and medical sciences now recognise the contribution that diet and individual foods may make to the reduction of disease, current EU law prevents the communication of these benefits to consumers, whereas the law on medicinal products is established on a very broad basis that also encompasses foods making preventive, therapeutic or curative claims. The concept 'disease risk reduction' as proposed by the European Commission Concerted Action on Functional Foods in Europe and other international bodies has been developed to reflect the 'health-promoting' properties of a food or food component in such a way as to facilitate such claims for risk reduction to be made outside the medical scope of the term 'prevention' (Richardson, 1996; Coppens et al. 2001). These new concepts of health claims, including disease risk reduction claims, reflect the fact that foods with health claims are aimed either at the healthy population or healthy individuals, recognising that the disease is not present, the cause of disease is multifactorial, including dietary, behavioural, environmental and genetic factors, and that the modification of certain dietary components alone cannot ensure that a disease will not develop, since it does not affect the other confounding factors. Nevertheless, the food or food component may help substantially to reduce the likelihood of getting the disease.

\section{The UK Joint Health Claims Initiative}

In the UK a strong consensus emerged that the present legal and enforcement frameworks governing health claims were both incomplete and inflexible, and that there was a need to review existing UK and EU laws where the communication of the role of a healthy diet in reducing the risk of disease is currently prohibited. The UK Joint Health Claims Initiative (JHCI), a tripartite group comprising regulatory authorities, the food industry and public interest organisations, established a voluntary code of practice for the use of health claims (Joint Health Claims Initiative, 2000). The claimed benefit must be scientifically valid, with evidence supporting the efficacy of the food (or foods) or food component(s) in human consumers under typical conditions of use and exposure. The JHCI developed an 'evidencebased' approach, which consisted of a systematic and objective compilation of all the scientific evidence relating to a particular health claim, including human intervention and observational studies, an evaluation of individual studies to determine the strengths and weaknesses of the data, a critical assessment of the data as a whole, and finally, a statement that there is significant scientific agreement that the body of evidence is sufficient to establish the validity of a health claim. The reviews are carried out by an independent panel of leading scientists in the UK. The totality of scientific evidence in support of the claim must be presented clearly and the documentation prepared in such a way as to demonstrate the claimed, specific physiological effect.

The experience gained in the UK in developing the JHCI code of practice, the formation of the expert committee and the process for the assessment of scientific evidence to support a health claim was utilised substantially in the EU Process for the Assessment of Scientific Support for Claims on Foods initiative.

\section{Wholegrain foods and CHD}

In February 2002 the JHCI expert committee and the council published its findings on a health claim for wholegrain foods and heart health (Joint Health Claims Initiative, 2002). The scientists concluded from the evidence presented in the scientific dossier that 'people with a healthy heart tend to eat more wholegrain foods as part of a healthy lifestyle', and that the 'totality of the evidence substantiates the health claim'. The details are shown in Table 1. The JHCI expert committee was asked to consider the question, 'Can an increased consumption of wholegrain foods help reduce the risk of coronary heart disease?' In the USA the Food and Drug Administration (FDA) authorised a health claim on 8 July 1999, which allows food companies to promote the heart disease- and cancer-fighting benefits of whole grains based on 'authoritative statements' from a federal scientific body, such as the National Institute of Health and Centers for Disease Control and Prevention, as well as from the National Academy of Sciences, as allowed by the FDA Modernization Act of 1997. The FDA-authorised claim states, 'Diets rich in wholegrain and other plant foods and low in total fat, saturated fat and cholesterol may reduce the risk of heart disease and some cancers' (US Food and Drug Administration, $1999 a, b)$. In the USA health claims are also 
Table 1. Generic claim assessment report of the expert committee to the Joint Health Claims Initiative (JHCl) council

$\mathrm{JHCl}$ has concluded its deliberations on a generic health claim for wholegrain foods and heart health. The claim may now be applied to appropriate foods under the conditions set out in the following report.

\begin{tabular}{ll}
\hline Date & Proposed generic health claim \\
\hline 2.4.02 & People with a healthy heart tend to eat more wholegrain foods as part of a healthy lifestyle \\
\hline The totality of the evidence substantiates the health claim $\quad$ Yes $\checkmark \quad$ No $\square$ \\
\hline
\end{tabular}

Points to note

1.

2.

3.

4.

5.

6.

The health impact on a diet containing wholegrain foods depends on the rest of the diet as well as other lifestyle factors such as exercise. The claim must be set within this context

The evidence supports an association between a healthy heart and wholegrain consumption but is insufficient to demonstrate cause and effect

The evidence is insufficient to support claims targeted specifically at men

The claim relates to foods containing $\geq 51 \%$ wholegrain ingredients by weight per serving. The term 'wholegrain' refers to the major cereal grains including wheat, rice, maize and oats. The structure for all grains is similar and the grain is made up of three components, the endosperm, the germ and the bran

The $\mathrm{JHCl}$ strongly recommends that companies seek advice from the Secretariat before using this claim to help ensure that the food product is consistent with good nutrition principles and complies with the $\mathrm{JHCl}$ Code of Practice for Health Claims on Food

The wording of the claim has been carefully formulated to reflect the evidence on which the claim has been approved. Wording may be altered, in consultation with the $\mathrm{JHCl}$, as long as the claim does not imply health benefits beyond the scope of the evidence; change the meaning of the claim; or, confuse consumers

authorised on the basis of an independent review of the scientific evidence and significant scientific agreement among qualified experts that the claims are factual and truthful. The FDA's stated intention is that the purpose of health claims is to benefit consumers by providing information on healthful eating patterns that may help reduce the risk of diseases such as heart disease and cancer. Manufacturers may use the health claims on complying foods to market their products. The claim is intended to help consumers identify foods containing whole grains and encourage greater consumption by describing relationships between whole grains and reduction of risk of disease. Although the JHCI has now given an authoritative endorsement that wholegrain foods are linked to a healthy heart, the current UK and EU food-labelling legislation prohibits the attribution to any foodstuff of the property of preventing, treating or curing a human disease or referring to such properties, i.e. reduction of risk of disease claims are not permitted currently.

\section{Definition of wholegrain}

Cereals are all plants of the grass family, the Gramineae. The grains are small separate seeds or seed-like dry fruits (caryopsis). The most important cereal grains in the UK are wheat, rice, maize, oats, rye and barley. The structure for all grains is similar and is made up of three components, the endosperm, the germ and the bran. As in the USA, whole grains consumed in the UK are generally subject to some type of processing and most of the whole grain is eaten in foods prepared with the use of pulverised forms, i.e. flours. Breakfast cereals are usually extended, shredded, flaked or puffed wholegrain foods.

Attention has been drawn to the different nomenclatures of 'grains' and 'cereals' in British English and American English in a paper by Jacobs (2001). The 'British English' terminology quoted by Jacobs (2001) includes: grain, cereal, wholegrain cereal, wholegrain flour, whole cereal food. Wholegrain foods that highlight the whole-grain content in a claim on food labels in the UK would automatically trigger the 'Quantitative Ingredient Declaration' legal requirement for percentage declaration in the ingredient list. Greater consumption of whole grains can be achieved by choosing foods that name the following ingredients, e.g. wheat flakes, cereal grains, wholegrain wheat, wholegrain rice, rolled oats, oatmeal and brown rice.

The American Association of Cereal Chemists (2000) approved a definition for wholegrain on 1 June 2000 as follows: 'Wholegrains shall consist of the intact, ground, cracked or flaked caryopsis, whose principal anatomical components - the starchy endosperm, germ and bran - are in the same relative proportions as they exist in the intact caryopsis'. All three structural components of the grain must be maintained during the processing and be present in the final product.

According to the US FDA, a food product is categorised as a wholegrain product if it contains $\geq 51 \%$ wholegrain ingredients by weight/reference amount customarily consumed (RACC) per d. This measure is equivalent to the concept already enshrined in UK vitamin and mineral claims legislation for the levels of the nutrient to be present in the 'amount of food that can be reasonably consumed in a day'. The same criterion has been applied to wholegrain products in the UK, with a view to harmonisation with the existing food law in the USA.

In the USA to consider a food as a 'wholegrain food', wholegrain should be present in sufficient quantity to characterise the food. The food must contain all portions of the kernel and provide a minimum of $16 \mathrm{~g}$ wholegrain/RACC. The US definition measures wholegrain percentage by weight/RACC because the RACC provides a consistent point of reference for foods of the same type. Furthermore, the RACC measurement produces a better representation of the foods providing wholegrain benefits because the RACC, 
unlike the serving size, will not result in foods being disqualified merely due to moisture content. For example, using a serving size of bread as 30-35 g, the majority of wholegrain breads would not qualify as wholegrain foods. However, using the $50 \mathrm{~g}$ RACC, wholegrain breads, which serve as important sources of grains, do qualify for the claim. The cereal fibre level (measured by the Association of Official Analytical Chemists method (AOAC, 2000)) is used to verify compliance with $3.0 \mathrm{~g} / 55 \mathrm{~g}$ RACC, $2.8 \mathrm{~g} / 50 \mathrm{~g}$ RACC, $2.5 \mathrm{~g} / 45 \mathrm{~g} \mathrm{RACC}$ and $1.7 \mathrm{~g} / 35 \mathrm{~g}$ RACC. In the USA the food must also meet the criteria for 'low fat' which is $3 \mathrm{~g}$ fat/RACC (and per $50 \mathrm{~g}$ if RACC is $\leq 30 \mathrm{~g}$ ), 'low saturated fat' which is $1 \mathrm{~g}$ saturated fat/RACC and $<15 \%$ energy from saturated fats, as well as a 'low cholesterol' which is $20 \mathrm{mg}$ cholesterol/RACC. Slavin et al. (2001) list a number of breads, breakfast cereals and snacks that qualify for the wholegrain health claim in the USA. The majority of the foods identified are also to be found in the UK. Typically, the major sources of whole grains are breads, breakfast cereals and crackers (Richardson, 2000).

\section{The process for the assessment of the wholegrain health claim}

\section{Identification of all relevant studies}

The scientific literature was searched for relevant articles using the keywords 'wholegrain and coronary heart disease' and 'wholegrain' for the period 1990-2001. Studies had to fulfil the following inclusion criteria: (1) to provide some dietary measure of whole grain intake; (2) to have used an outcome measurement related to CHD events or mortality; (3) only primary studies, systematic reviews or otherwise comprehensive reviews that filled the two first criteria were eligible for inclusion. Exclusion criteria for the studies were: (1) primary studies that have measured only the intake of dietary or cereal fibre in relation to CHD events; (2) primary studies that have investigated the impact of whole grains on different risk factors of $\mathrm{CHD}$; (3) primary studies that have investigated the relationship between whole grain consumption and coronary vascular diseases other than CHD, e.g. stroke, diabetes; (4) narratives and general reviews of the topic, because they did not provide primary evidence.

Studies conducted before 1996 will have measured dietary or cereal-fibre intake without specifying the source of fibre. For 'wholegrain and coronary heart disease' ten articles were found between 1999 and 2001 (from which all the abstracts were read), five full articles were retrieved and two were included as evidence. For 'wholegrain' 125 articles were found between 1998 and 2001, thirty-five abstracts were read, seven articles were retrieved and five were included as evidence. A total of seven references were included in the scientific dossier.

\section{Evaluation of individual references}

Cohort studies. Summaries of the four cohort studies are shown in Tables 2 and 3. In each study the relative risk or hazard rate ratio for the incidence of CHD for the highest consumption of whole grains is compared with that for the lowest consumption of whole grains.
Systematic review. A meta-analysis by Anderson et al. (2000) systematically reviewed literature from the past 20 years in order to evaluate an association between dietary fibre and CHD and to examine the strength and consistency of evidence that links whole grain intake to protection from CHD. The inclusion criteria for the systematic review were: (1) provision of some dietary measure related to whole grain intake or dietary fibre intake; (2) outcome data related to CHD events; (3) estimation of the variance that allowed the authors of the individual studies to make variance-adjusted calculations. For the period 1966-1999, twenty-nine published reports met the initial criteria. Only three studies specifically reported whole grain intake and allowed comparison for this criterion. A fourth study reported wholewheat bread intake and was included with those reporting whole grain intake. Only twelve of the reports met all three inclusion criteria and had sufficient data for inclusion in the meta-analysis statistical computations. The primary outcome measures were CHD events and CHD deaths. After pooling of study data the strongest inverse association was between wholegrain and wholewheat bread intakes and risk of CHD. For those twelve population-based cohort studies included in the meta-analysis, those individuals with the highest intake of whole grain had an adjusted relative risk for CHD of 0.74 (95\% CI 0.64, 0.84) compared with individuals consuming the lowest intake of whole grain. These studies also suggested that an intake of three servings of whole grain per $\mathrm{d}$ might have an important cardio-protective effect. The tabulated summary of twentynine published reports provides a qualitative overview of the effects of different foods and fibre sources on risk for CHD. Consumption of whole grain and total dietary fibre had the strongest and most consistent association with protection from CHD.

Critical review. Truswell (2002) examined the question whether there is a relationship between cereal consumption and CHD. Studies comprising this impressive review included those published between 1969 and 1990 that examined the relationship between wheat fibre and plasma cholesterol, those published between 1963 and 1994 that examined the relationship between oat fibre and plasma cholesterol, prospective cohort studies published between 1996 and 2001 that related cereal grains to CHD, and a single randomised controlled secondary-prevention trial over 2 years that examined the effect of increased consumption of cereal fibre on CHD recurrence.

The review included those cohort studies already referred to in Tables 2 and 3. Truswell (2002) summarised five separate very large prospective cohort studies in the USA, Finland and Norway, which were based on over 98000 men and 109000 women. All five cohorts showed that subjects consuming relatively large amounts of wholegrain cereals had significantly lower rates of CHD. The conclusion was that the protective effect did not seem to be due to cholesterol lowering. Part of the effect may be due to folic acid and/or vitamin $\mathrm{E}$ and/or effects of glucose and insulin responses and/or haemostatic factors. From the available evidence, none of these factors can be singled out as a major mechanism for protection from CHD. It is more probable that whole grains contain several synergistic protective factors. Truswell (2002) concluded that it appears valid to 
Table 2. Evaluation of individual references: summary of background information on four cohort studies

\begin{tabular}{|c|c|c|c|c|c|c|c|c|}
\hline Reference & $\begin{array}{c}\text { Objective of } \\
\text { study }\end{array}$ & $\begin{array}{l}\text { Study } \\
\text { design }\end{array}$ & $\begin{array}{c}\text { Study } \\
\text { population }\end{array}$ & $\begin{array}{c}\text { Duration of } \\
\text { study }\end{array}$ & $\begin{array}{l}\text { Location } \\
\text { of study }\end{array}$ & Methodology & $\begin{array}{c}\text { Outcome } \\
\text { measurement }\end{array}$ & $\begin{array}{l}\text { Statistical } \\
\text { analysis }\end{array}$ \\
\hline $\begin{array}{l}\text { Jacobs et al. } \\
\qquad(2001)\end{array}$ & $\begin{array}{l}\text { Whether mor- } \\
\text { tality and } \\
\text { death from } \\
\text { CHD and } \\
\text { total CVD is } \\
\text { reduced } \\
\text { among } \\
\text { wholegrain } \\
\text { bread eaters } \\
\text { in Norway }\end{array}$ & $\begin{array}{l}\text { Prospective } \\
\text { cohort } \\
\text { study }\end{array}$ & $\begin{array}{l}16933 \text { men } \\
\text { and } 16915 \\
\text { women aged } \\
\text { 35-56 years } \\
\text { at baseline, } \\
\text { not disabled } \\
\text { and free from } \\
\text { CVD }\end{array}$ & $\begin{array}{l}\text { A follow-up } \\
\text { period from } \\
1977-1983 \\
\text { to } 1994 \\
\text { i.e. } 11-17 \\
\text { years }\end{array}$ & $\begin{array}{l}\text { Norway, } \\
\text { three } \\
\text { different } \\
\text { counties }\end{array}$ & $\begin{array}{l}\text { Dietary assessment } \\
\text { using validated } \\
\text { semi-quantitative, } \\
\text { sixty-six-item food- } \\
\text { frequency question- } \\
\text { naire that focused } \\
\text { on bread, meat, } \\
\text { fish, milk, fat, etc. A } \\
\text { wholegrain bread } \\
\text { score was } \\
\text { formulated }\end{array}$ & $\begin{array}{l}\text { Cause of } \\
\text { death using } \\
\text { interna- } \\
\text { tional classi- } \\
\text { fication, } \\
\text { total mortal- } \\
\text { ity, underly- } \\
\text { ing causes } \\
\text { of CHD and } \\
\text { total CVD }\end{array}$ & $\begin{array}{l}\text { Participants } \\
\text { divided into } \\
\text { five catego- } \\
\text { ries according } \\
\text { to wholegrain } \\
\text { bread intake } \\
\text { score. Propor- } \\
\text { tional hazards } \\
\text { regression } \\
\text { analysis used }\end{array}$ \\
\hline $\begin{array}{l}\text { Liu et al. } \\
\text { (1999) }\end{array}$ & $\begin{array}{l}\text { Whether high } \\
\text { whole grain } \\
\text { intake } \\
\text { reduces risk } \\
\text { of } \mathrm{CHD} \text { in } \\
\text { women }\end{array}$ & $\begin{array}{l}\text { Prospective } \\
\text { cohort } \\
\text { study }\end{array}$ & $\begin{array}{l}75521 \text { women } \\
\text { aged 38-63 } \\
\text { years. No } \\
\text { previous } \\
\text { diagnosed } \\
\text { diabetes, } \\
\text { angina, myo- } \\
\text { cardial infarc- } \\
\text { tion, stroke or } \\
\text { other CVD }\end{array}$ & $\begin{array}{l}\text { 1984-1994, } \\
\text { i.e. } 10 \\
\text { years } \\
\\
\text { r- }\end{array}$ & USA & $\begin{array}{l}\text { Dietary assessments } \\
\text { using validated } \\
\text { semi-quantitative } \\
\text { 126-item food- } \\
\text { frequency question- } \\
\text { naire. Wholegrain } \\
\text { foods included } \\
\text { bread, breakfast } \\
\text { cereals, wheat } \\
\text { germ, brown rice, } \\
\text { bran etc }\end{array}$ & $\begin{array}{l}\text { Primary end } \\
\text { point was } \\
\text { incident } \\
\text { CHD includ- } \\
\text { ing fatal and } \\
\text { any non- } \\
\text { fatal myo- } \\
\text { cardial } \\
\text { infarction }\end{array}$ & $\begin{array}{l}\text { Pooled logistic } \\
\text { regressions } \\
\text { with 2-year } \\
\text { intervals. RR } \\
\text { was adjusted } \\
\text { for age, smok- } \\
\text { ing, BMI, HRT, } \\
\text { alcohol intake, } \\
\text { exercise etc }\end{array}$ \\
\hline $\begin{array}{c}\text { Jacobs et al. } \\
\quad(1999)\end{array}$ & $\begin{array}{l}\text { Whether } \\
\text { nutrient-rich } \\
\text { whole grains } \\
\text { reduce mor- } \\
\text { tality risk of } \\
\text { different } \\
\text { diseases }\end{array}$ & $\begin{array}{l}\text { Prospective } \\
\text { cohort } \\
\text { study }\end{array}$ & $\begin{array}{l}38740 \text { women } \\
\text { aged } 55-69 \\
\text { years }\end{array}$ & $\begin{array}{c}\text { 1986-1995, } \\
\text { i.e. } 9 \text { years }\end{array}$ & lowa, USA & $\begin{array}{l}\text { Dietary assessment } \\
\text { using validated } \\
\text { 127-item food- } \\
\text { frequency question- } \\
\text { naire. Participants } \\
\text { asked to name } \\
\text { usual breakfast } \\
\text { cereal }\end{array}$ & $\begin{array}{l}\text { Cause of } \\
\text { death using } \\
\text { interna- } \\
\text { tional classi- } \\
\text { fication }\end{array}$ & $\begin{array}{l}\text { Proportional haz- } \\
\text { ards regres- } \\
\text { sion analysis. } \\
\text { Food group } \\
\text { variables cate- } \\
\text { gorised by } \\
\text { quintiles. Anal- } \\
\text { ysis adjusted } \\
\text { for age, energy } \\
\text { intake, other } \\
\text { risk factors } \\
\text { and lifestyle } \\
\text { behaviours }\end{array}$ \\
\hline $\begin{array}{c}\text { Jacobs et al. } \\
\qquad(1998)\end{array}$ & $\begin{array}{l}\text { Examine } \\
\text { hypothesis } \\
\text { that whole } \\
\text { grain intake } \\
\text { is associ- } \\
\text { ated with a } \\
\text { reduced risk } \\
\text { of IHD and } \\
\text { death }\end{array}$ & $\begin{array}{l}\text { Prospective } \\
\text { cohort } \\
\text { study }\end{array}$ & $\begin{array}{l}34492 \text { post- } \\
\text { menopausal } \\
\text { women aged } \\
55-69 \text { years } \\
\text { free of IHD at } \\
\text { baseline }\end{array}$ & i.e. 9 years 1 & Iowa, USA & $\begin{array}{l}\text { Dietary assessment } \\
\text { using validated } \\
127 \text {-item food- } \\
\text { frequency question- } \\
\text { naire to estimate } \\
\text { whole grain and } \\
\text { refined grain } \\
\text { intakes. Serving } \\
\text { size and frequency } \\
\text { of consumption } \\
\text { specified. Partici- } \\
\text { pants asked to } \\
\text { name usual break- } \\
\text { fast cereal }\end{array}$ & $\begin{array}{l}\text { Death from } \\
\text { IHD using } \\
\text { interna- } \\
\text { tional classi- } \\
\text { fication }\end{array}$ & $\begin{array}{l}\text { Proportional haz- } \\
\text { ards regres- } \\
\text { sion analysis. } \\
\text { Individual and } \\
\text { grouped die- } \\
\text { tary variables } \\
\text { categorised by } \\
\text { quintiles }\end{array}$ \\
\hline
\end{tabular}

CVD, coronary vascular disease; RR, relative risk; HRT, hormone replacement therapy.

make health claims that wholegrain cereal foods may reduce the risk of CHD.

\section{The totality of the evidence}

After the individual references have been identified and their strengths and weaknesses assessed, the totality of the evidence needs to be evaluated. In the UK the JHCI expert committee determined the weight of evidence, including the consistency of results across different studies, the study designs, the magnitude of the effect, the strength of the association, statistical validity, etc. Their overall assessment, as described in Table 1, involved critical interpretation of the data as a whole and the experts' application of scientific judgement. The final decision involved judging the relationship between whole grain consumption and heart health to be valid when the evidence in support outweighs the evidence against. In this case, as set out in Table 1, the JHCI 
Table 3. Evaluation of individual references: summary of results and conclusions of four cohort studies

\begin{tabular}{|c|c|c|}
\hline Author & Results & Conclusions and points to note \\
\hline $\begin{array}{c}\text { Jacobs et al. } \\
(2001)\end{array}$ & $\begin{array}{l}\text { Men and women reported eating } 6.3 \text { (SD 2.0) and } 3.9 \text { (SD 1.6) } \\
\text { slices of bread/d respectively; after adjustment for age and } \\
\text { energy intake the mean WGBS was the same for men and } \\
\text { women; wholegrain-bread eaters had a more favourable pro- } \\
\text { file of health behaviours and diet than non-eaters; comparing } \\
\text { the highest } v \text {. the lowest WGBS, the multivariate adjusted } \\
\text { HRR for men and women combined was } 0.76 \text { ( } 95 \% \mathrm{Cl} 0.56 \text {, } \\
1.02 \text { ) }\end{array}$ & $\begin{array}{l}\text { Reduced death rates in healthy, middle-aged Norwegian whole- } \\
\text { grain eaters in several disease categories; association } \\
\text { between greater wholegrain bread intake with reduced mor- } \\
\text { tality most consistently graded for CVD; study extends US } \\
\text { findings for differential risk according to amount of whole } \\
\text { grain intake to higher intake levels customarily consumed by } \\
\text { Norwegians; all dietary surveys suffer from high within- } \\
\text { individual error in self-reported diets, major limitation is lack of } \\
\text { information about fruit and vegetable intakes }\end{array}$ \\
\hline $\begin{array}{l}\text { Liu et al. } \\
\text { (1999) }\end{array}$ & $\begin{array}{l}\text { Medium intake of whole grain ranged from virtually none in the } \\
\text { lowest quintile to about three servings per d in highest quin- } \\
\text { tile; women with high intakes of wholegrain foods had a } \\
\text { more favourable profile of health behaviours than those with } \\
\text { low intakes; study demonstrates strong inverse associations } \\
\text { between whole grain consumption and risk of CHD; the multi- } \\
\text { variate adjusted RR of CHD was } 0.74(95 \% \mathrm{Cl} 0.58,0.94) \\
\text { for the highest compared with the lowest quintile; contribu- } \\
\text { tion of individual foods including wholegrain breakfast cereals } \\
\text { showed significant inverse associations with CHD }\end{array}$ & $\begin{array}{l}\text { Strong inverse association between whole grain intake and risk } \\
\text { of CHD; associations independent of both dietary and non- } \\
\text { dietary coronary risk factors; misclassification of intake is a } \\
\text { possibility, but questionnaire assessment had a relative high } \\
\text { accuracy; difficult to distinguish effect of different grains within } \\
\text { whole- or refined-grain categories; protective effect is unlikely } \\
\text { to be limited to only one source of whole grain; in this cohort } \\
\text { protective effects of wholegrain derived from several different } \\
\text { sources }\end{array}$ \\
\hline $\begin{array}{c}\text { Jacobs et al. } \\
\text { (1999) }\end{array}$ & $\begin{array}{l}\text { Mean weekly intake of wholegrain foods was eleven servings, } \\
\text { with dark bread and breakfast cereals providing the largest } \\
\text { parts. In the lowest quintile there was virtually no consump- } \\
\text { tion of wholegrain foods, one to two servings per d in quintile } \\
3 \text { and three to four servings per } d \text { in the highest quintile; } \\
\text { those who ate wholegrain foods had higher socio-economic } \\
\text { status and positive health behaviours; there were striking } \\
\text { inverse associations between wholegrain intake with risk of } \\
\text { major causes of death, except stroke; the multivariate HRR } \\
\text { for CHD was } 0.82(85 \% \mathrm{Cl} 0.63,1.06)\end{array}$ & $\begin{array}{l}\text { During } 9 \text { years of follow-up, women who reported eating at least } \\
\text { one serving per d of wholegrain foods had substantially lower } \\
\text { risk of mortality, including mortality from CVD and CHD com- } \\
\text { pared with women who reported eating almost no whole } \\
\text { grains; HRR was observed to be relatively constant for quin- } \\
\text { tiles 3-5 of whole grain intake, and it is unclear if this result is } \\
\text { an artifact or a time threshold level; food-frequency question- } \\
\text { naires may be the source of unreliability, and they have a } \\
\text { limited ability to distinguish between whole and refined grain }\end{array}$ \\
\hline $\begin{array}{c}\text { Jacobs et al. } \\
\quad(1998)\end{array}$ & $\begin{array}{l}\text { Mean weekly intake of wholegrain foods was } 10.8 \text { servings, } \\
\text { with dark bread and breakfast cereals providing the largest } \\
\text { parts; the medium intake of wholegrain foods ranged from } \\
1.5 \text { to } 22.5 \text { servings per week from the lowest to the highest } \\
\text { quintiles of intakes; higher intakes were associated with more } \\
\text { education and better health and diet behaviours; there was a } \\
\text { striking inverse association between whole grain intake and } \\
\text { risk of death from IHD; the multivariate adjusted RR was } 0.70 \\
(95 \% \mathrm{Cl} 0.5,0.98) \text {; the association of whole grain intake with } \\
\text { IHD death was independent of intake of refined grain }\end{array}$ & $\begin{array}{l}\text { Study comprehensively assesses whole grain intake and finds } \\
\text { an association between higher intake and lower risk of IHD } \\
\text { death in post-menopausal women who were initially free of } \\
\text { IHD; other dietary factors may also play a role in the aetiology } \\
\text { of IHD; study analysis defined levels of intake, but perplexing } \\
\text { result was upturn in observed risk in the highest quintile of } \\
\text { intake compared with fourth quintile; this result may be an } \\
\text { artifact or a threshold with intake of whole grain > one serving } \\
\text { per d }\end{array}$ \\
\hline
\end{tabular}

WGBS, wholegrains bread score; HRR, hazard rate ratio; CVD, coronary vascular disease; RR, relative risk.

concluded that the totality of the evidence was sufficient to permit the conclusion that a change in dietary intake is likely to result in a health benefit.

\section{Assessment of significant scientific agreement}

The Process for the Assessment of Scientific Support for Claims on Foods initiative (International Life Sciences Institute Europe, 2001; Richardson et al. 2003) stressed that the use of health claims should be subjected to rigorous substantiation on a case-by-case basis. In the case of the whole grain health claim, the scientific information is published via peer-reviewed journals and all the relevant evidence was made available to the scientific assessors. Significant scientific agreement is a useful concept that refers to the extent of agreement among qualified experts in the appropriate field, and it also reflects the process of scientific discovery. The JHCI states that the evidence supports an association between a healthy heart and whole grain consumption but is insufficient to demonstrate cause and effect. At this time it is not clear whether whole grain consumption is simply a marker of a healthy lifestyle and whether other dietary factors and confounding factors influence the beneficial outcomes on health. However, there is no doubt that the observational data support an association between a healthy heart and a healthy lifestyle that includes regular consumption of wholegrain foods.

\section{Recommended levels of consumption}

Substantial attention has already been paid to the health effects of saturated fats and fruit and vegetables, but scant attention has so far been directed to the importance of whole grains in public health policy. The UK JHCI expert committee has approved a health claim that 'decreasing dietary saturates (saturated fat) can help lower blood cholesterol' and has published its views on the role of eating more fruit and vegetables and reduced risk of CHD and certain 
cancers (Joint Health Claims Initiative, 2002). Together with the whole grain health claim, these three nutrition messages could spearhead an educational effort and have a profound impact on the health of populations in the EU.

Food grains are staple foods that form the base of the Food Guide Pyramid in the USA, with the US Department of Agriculture recommending six to eleven servings of grains per $\mathrm{d}$, of which at least three servings should consist of a variety of wholegrain foods (US Department of Agriculture, 1997). Further to the US dietary guidelines (US Department of Agriculture, 2000), there have been several papers that have made quantified recommendations for at least three servings of wholegrain foods per d. Anderson et al. (2000) concluded that their meta-analysis suggested an intake of three servings of whole grain per $d$ because of the cardio-protective effect. Slavin et al. (2001) concluded that dietary intake studies indicated that consumption of whole grain is far less than the recommended intake of three servings per d, with an average current daily intake of one or fewer servings per d. Anderson \& Hanna (1999) concluded that two to three servings of whole grain per $d$ may have marked benefits in the prevention of cardiovascular disease. In the study by Liu et al. (1999), those in the highest quintile of consumption of whole grain (median 2.7 servings per d) had a $30 \%$ decreased rate of $\mathrm{CHD}(P<0.001)$ relative to those in the lowest quintile (median 0.13 servings per $d$ ). Jacobs et al. (1998) showed that whole grain intakes were (median servings per d) $0.2,0.9,1.2,1.9$ and 3.2 for quintiles of intake. A clear inverse relationship between whole grain intake and risk of CHD death existed, and the lower risk was associated with higher whole grain intake. Cleveland et al. (2000) concluded that consumption of wholegrain foods by US adults falls well below the recommended level. This paper also highlights the new US national nutrition objectives for the year 2010, which for the first time included an objective that targeted whole grain intake. The US Department of Agriculture and the American Dietetic Association jointly proposed the message ' 3 ARE KEY' to specifically quantify guidance on the number of servings of whole grain to eat daily. The paper also sets out the US Department of Agriculture objective to track progress and to monitor the percentage of selected populations consuming six or more grain servings daily, the percentage consuming three or more whole grain servings daily, and the percentage meeting the dual dietary goals simultaneously.

The first analysis of wholegrain food consumption in the UK was undertaken by the Medical Research Council, Human Nutrition Research in Cambridge (Lang et al. 2001). The analysis of two cross-sectional nationallyrepresentative dietary and nutritional surveys (Dietary and Nutritional Survey of British Adults (Gregory et al. 1990); the National Diet and Nutrition Survey: People Aged 65 Years or Over (Finch et al. 1998)), highlighted the extremely low consumption of wholegrain foods within the British population. For those aged $\geq 65$ years, the weekly average was less than five servings; in younger adults aged 16-64 years the weekly average was only 2.5 servings. Approximately one-third of British adults failed to consume any wholegrain foods and $>90 \%$ consumed less than three servings per d. Although the study did not quantify whole grain intake in terms of actual amount consumed, these initial results are a major cause for concern.

\section{Positive messages about diet and health}

Individuals are more likely to achieve a dietary goal if the message is communicated in terms of servings of specific foods rather than weight or percentages of individual nutrients (Richardson \& Brady, 1997). Moreover, positive messages are more likely to succeed, whereas a plethora of negative nutrition messages tend to be counterproductive (Richardson, 2000). Where there is good scientific consensus and agreement among all the interested parties, it would be sensible if the policy makers could focus on a few specific key nutrition and lifestyle messages, including choosing daily a variety of fruits, vegetables and grains, especially whole grains and a healthy level of physical activity.

The objective of the public health messages should be to:

raise awareness of the health benefits of whole grains for maintaining cardiovascular health and to increase consumption of wholegrain-containing foods by creating demand for palatable wholegrain products (Smith et al. 2001a,b);

demonstrate that wholegrain foods, along with fruit and vegetables, are 'packages' of nutrients, phyto-protective components and fibre, and that the package works synergistically to be greater than the sum of its parts; focus on the fact that grains and whole grains are staple foods that form the basis of the UK Food Plate Guide; develop whole grain messages that can be communicated effectively through health professionals, teachers, nutrition educationalists and health-promotion leaflets, the media etc. to help consumers identify wholegrain foods and products.

In addition to the public health messages about the benefits of whole grains, manufacturers of complying products who wish to make a health claim have to ensure that the wording of the claim does not go beyond the scope of the evidence, is truthful and is not misleading. The JHCI method of approval is based on a 'statement of scientific linkage', with flexibility in communicating the claims, provided the meaning for the intended consumer is not altered. Consumer communication is a complex and specialised subject and is a matter for close collaboration between those who are knowledgeable in the areas of science, food law and marketing. An example of a health claim used in labelling and advertising under current UK legislation is 'whole grain may help to maintain a healthy heart when eaten as part of a low-fat diet and a healthy lifestyle'. In the future, following the new proposals for legislation (Commission of the European Communities, 2002), it may be possible to communicate in the EU that wholegrain cereal foods may reduce the risk of CHD, along similar lines to those already stated in the US FDA health claim for whole grain.

\section{Conclusion: whole grain claims and the fulfilment of the objectives of the Joint Health Claims Initiative code}

The objectives of the JHCI code of practice on health claims (Joint Health Claims Initiative, 2000) take into account: 
protecting and promoting public health, e.g. including the provision of information on healthful eating patterns such as increased consumption of wholegrain cereals; providing accurate and responsible information relating to food to enable consumers to make informed choices, e.g. the use of whole grain health claims on complying foods and in educational and promotional material; promoting fair trade and innovations in the food industry, e.g. stimulating the development of palatable food products that utilise more whole grain ingredients; promoting consistency in the use of health claims in the UK, EU and internationally, e.g. development of a panEuropean health claim on the benefits of whole grain.

Wholegrain foods are important sources of nutrients and phyto-protective components, which are in short supply in many member states of the EU including the UK. Encouraging the public to increase consumption of wholegrain foods is a positive health message that has critical public health implications (Richardson, 2000). Increasing the variety and availability of acceptable wholegrain foods is also important. The major food sources of whole grains are bread and wholegrain breakfast cereals. Whole grain is the primary ingredient in some ready-to-eat cereals and eating a wholegrain cereal for breakfast each day is one of the easiest ways to include whole grains in the diet.

The physiological effects of whole grains and their role in improving health are, as yet, only partly understood. Many studies are now underway internationally to identify the important components and especially the biological mechanisms behind the observed health benefits.

\section{Acknowledgements}

The author acknowledges the help and guidance of the Joint Health Claims Initiative Council, Expert Committee and Executive Secretary, Melanie Ruffell, during the development of the JHCI process for the assessment of scientific support for health claims in the UK and thanks Mrs Kirsti Peltola for the literature search and critical reviews of key references included in the scientific dossier on wholegrain. The preparation of the dossier was funded by Cereal Partners UK Ltd.

\section{References}

American Association of Cereal Chemists (2000) AACC Members Agree on Definition of Whole Grain. St Paul, MN: American Association of Cereal Chemists; available at www.scisoc.org/aacc

Anderson JW \& Hanna TJ (1999) Wholegrains and protection against coronary heart disease: what are the active components and mechanisms? American Journal of Clinical Nutrition 70, 307-308.

Anderson JW, Hanna TJ, Peng X \& Kryscio RJ (2000) Wholegrain foods and heart disease risk. Journal of the American College of Nutrition 19, 291S-299S.

Association of Official Analytical Chemists (2000) Official Methods of Analysis, 17th edition. Gaithersburg, MD, USA: Association of Official Analytical Chemists.

Bellisle F, Diplock AT, Hornstra G, Koletzko B, Roberfroid M, Salminen S \& Saris WHM (editors) (1998) Functional food science in Europe. British Journal of Nutrition 80, Suppl. 1, S1S193.
Cleveland LE, Moshfegh AJ, Albertson AM \& Goldman JD (2000) Dietary intake of wholegrains. Journal of the American College of Nutrition 19, 331S-338S.

Commission of the European Communities (2002) Draft Proposal for Regulation of the European Parliament and of the Council on Nutrition, Functional and Health Claims Made on Foods. Working Document, SANCO/1832/2002. Brussels, Belgium: Commission of the European Communities.

Coppens P, Biljsma M, Craddock N, Herreman I, Hurt E, Le BailCollet Y \& Loosen P (2001) Are foods bearing health claims medicinal products? Scandinavian Journal of Nutrition 45, 140-145.

Diplock AT, Aggett PJ, Ashwell M, Bornet F, Fern EB \& Roberfroid MB (1999) Scientific concepts of functional foods in Europe: consensus document. British Journal of Nutrition 81, S1-S27.

Finch S, Doyle W, Lowe C, Bates CJ, Prentice A, Smithers G \& Clarke PC (1998) National Diet and Nutrition Survey: People aged 65 Years and Over. vol. 1, Report of the Diet and Nutrition Survey. London: The Stationery Office.

Gregory J, Foster K, Tyler H\& Wiseman M(1990) Dietary and Nutritional Survey of British Adults. London: H.M. Stationery Office.

International Life Sciences Institute Europe (2001) Process for the Assessment of Scientific Support for Claims on Foods (PASSCLAIM). A European Commission (1995) Concerted Action Programme Supported by the European Commission DG Research, Thematic Programme 1 Quality of Life and Management, Key Action 1-Health, Food and Nutrition. Brussels, Belgium: ILSI Europe.

Jacobs DR Jr (2001) Grain v. cereal: an impediment to public understanding of food and a study in language. British Journal of Nutrition 86, 543-544.

Jacobs DR Jr, Meyer HE, Kushi LH \& Folsom AR (1998) Wholegrain intake may reduce the risk of ischemic heart disease death in postmenopausal women. The Iowa Women's Health Study. American Journal of Clinical Nutrition 68, 248-257.

Jacobs DR Jr, Meyer HE, Kushi LH \& Folsom AR (1999) Is wholegrain intake associated with reduced total and cause-specific death rates in older women? The Iowa Women's Health Study. American Journal of Clinical Nutrition 89, 322-329.

Jacobs DR Jr, Meyer HE \& Solvoll K (2001) Reduced mortality among wholegrain bread eaters in men and women in the Norwegian County Study. European Journal of Clinical Nutrition 55, 137-143.

Joint Health Claims Initiative (2000) Code of Practice on Health Claims on Foods. Leatherhead, Surrey: Leatherhead Food Research Association.

Joint Health Claims Initiative (2002) Generic Claims Assessments. www.jhci.co.uk

Lang R, Jebb SA, Thane CW \& Bolton-Smith C (2001) Consumption of Wholegrain Foods in the UK. Cambridge: MRC Human Nutrition Research.

Leatherhead Food Research Association (2001) European Health Claims Forum Conference Proceedings, pp. 1-82. Leatherhead, Surrey: Leatherhead Publishing.

Liu S, Stampfer MJ, Hu FB, Giovannucci E, Rimm E, Manson J \& Hennekens CH (1999) Wholegrain consumption and risk of coronary heart disease: results from the Nurses' Health Study. American Journal of Clinical Nutrition 70, 412-419.

Richardson DP (1996) Functional foods - shades of grey: an industry perspective. Nutrition Reviews 54, S174-S185.

Richardson DP (2000) The grain, the wholegrain and nothing but the grain: the science behind wholegrain and the reduced risk of heart disease and cancer. British Nutrition Foundation Bulletin 25, 353-360.

Richardson DP, Affertsholt T, Asp N-G, Bruce Å, Grossklaus R, Howlett J, Ross R, Verhagen H \& Viechtbauer V (2003) Process 
for the assessment of scientific support for claims on food. European Journal of Nutrition 42 (In the Press).

Richardson DP \& Brady M (1997) The UK food and drink manufacturing industry response to the Health of the Nation: a strategy for health. British Food Journal 99, 220-232.

Slavin JL, Jacobs D, Marquart L \& Weimer K (2001) The role of wholegrains in disease prevention. Journal of the American Dietetic Association 101, 780-785.

Smith A, Kuznesof S, Richardson DP \& Seal CJ (2001a) Effectiveness of dietary intervention strategies aimed at increasing consumption of wholegrain or low and reduced fat products in free-living volunteers. Proceedings of the Nutrition Society 60, 178A.

Smith A, Richardson DP, Kuznesof S \& Seal CJ (2001b) Effectiveness and acceptability of a dietary intervention to increase consumption of wholegrain products in free-living individuals. In Wholegrain and Human Health, pp. 32-35 [K
Liukkonen, A Kuokka and $\mathrm{K}$ Poutanen, editors]. Espoo, Finland: VTT Technical Research Centre of Finland.

Truswell AS (2002) Cereal grains and coronary heart disease. European Journal of Clinical Nutrition 56, 1-14.

US Department of Agriculture (1997) Pyramid Servings Data Results from USDA's 1994-1996 Continuing Survey of Food Intake by Individuals. Riverdale, CA: Food Surveys Research Group.

US Department of Agriculture (2000) Nutrition and your Health: Dietary Guidelines for Americans 2000. Washington, DC: USDA.

US Food and Drug Administration (1999a) Health Notifications for Wholegrain Foods. http://vm.cfsan.fda.gov/ dms/flgrains. html

US Food and Drug Administration (1999b) Wholegrain Foods. Authoritative Statement Claim Notification, Docket 99p-2209. Washington, DC: US Government Printing Office. 